\title{
MANAGEMENT OF Ralstonia solanacearum (POTATO WILT DISEASE) VIRULENCE BY USING BIOACTIVE COMPOUNDS
}

\author{
Karim, Z., M. S. M. Chowdhury ${ }^{1}$ and M. S. Hossain ${ }^{2}$ \\ Plant Pathology Division, Bangladesh Agricultural Research Institute (BARI), Joydebpur, Gazipur- \\ 1701, Bangladesh; 'Department of Plant Pathology, Sher-E-Bangla Agricultural University, Agargaon, \\ Dhaka-1207, Bangladesh; ${ }^{2}$ Department of Entomology, Sher-E-Bangla Agricultural University, \\ Agargaon, Dhaka-1207, Bangladesh
}

\begin{abstract}
Potato is an important vegetable crop of Bangladesh which is facing challenges worldwide due to a quarantine pathogen, Ralstonia solanacearum. It is a very successful bacterial pathogen against most of the traditional management practices. Suspension of ten bioactive compounds viz. propolis, honey, turmeric powder+oil, turmeric powder, magnesium chloride, boiled rice fluid, boiled rice fluid+iodine, sun dried cow dung powder, honey+iodine and sodium bicarbonate were evaluated and compared with control (sterile water), commercial bactericide (Krosin AG) and farmers practice (stable bleaching powder). In vitro assessment was done by comparing the inhibition zones produced on TZC (tetrazolium chloride) solid medium in disc diffusion method. All of those compounds produced larger inhibition zones as compared to control which indicated the effectiveness of the test compounds against the bacteria. To screen out the performances of those compounds in vivo, potato seedlings were inoculated in sterilized soil by soil soak method. Later, mature plants were inoculated in unsterilized soil to find the better resulting compound(s) in field soil condition against the disease. Finally, suspension of cow dung (@25\%), propolis (@6mg/ml) and turmeric powder (@25\%)were selected for trial as soil and seed treatment against the pathogen. It was found that, cow dung reduced $28.89 \%$ disease severity index which was followed by $26.67 \%$ in propolis and $22.22 \%$ in turmeric powder as compared to control $(84.44 \%)$ in artificially inoculated potato plants against $R$. solanacearum.
\end{abstract}

Key words: Bacterial wilt; Potato; Ralstonia solanacearum; Management; Bioactive compounds.

\section{INTRODUCTION}

Potato (Solanum tuberosum L.) is considered a super vegetable as well as a versatile source of food security. It is the $4^{\text {th }}$ most important crop after wheat, rice and maize in the world (FAOSTAT 2014). Bangladesh is the $7^{\text {th }}$ producer of potato in the world by producing 86.03 lakh tons of potato. Yet, the yield of potato is quite lower than the yield of Ireland and India (FAOSTAT 2017). The reasons behind lower yield of potato include- inadequate supply of quality seeds, poor soil health, different pests and diseases etc. Considering the diseases of potato, soil borne diseases alone can cause a yield loss of as much as 10-20\% of potato annually (USDA 2003) and among them wilt or brown rot caused by Ralstonia solanacearum is the most destructive one (Yuliar et al. 2015). The disease challenges the potato industry by causing yield losses and quarantine concerns throughout the world in temperate, subtropical and tropical regions (CABI 2017, Champoiseau et al. 2009). It is responsible for an estimated loss of US \$1 billion each year and, the disease has been estimated to affect three million farm families for about 1.7 million hectares of potatoes approximately in 80 countries (Champoiseau et al. 2009). In India, this disease causes $50 \%$ crop loss in potato in a regular manner (Mukherjee and Dasgupta 1989) which goes up to 75\% losses as reported in some areas of Karnataka (Gadewar et al. 1991) and it emerged as a major constraint for potato cultivation from 2007 in Madhya Pradesh (India) by causing heavy crop losses (Sagar et al. 2013). In Bangladesh more than 30\% of potato crops get affected by $R$. solanacearum, with more than $14 \%$ yield reduction (Karim et al. 2018). A temporary ban was imposed by Russia on the entry of potatoes from Bangladesh in May 2015 on food safety grounds after detecting this organism in the exported potatoes (Parvez 2017). 
Due to the biological nature of "heterogeneous species complex" (capable of showing higher variability in biochemical properties in different type of environment), $R$. solanacearum became very successful to compromise the barriers of traditional management practices (Karim et al. 2018). However, several bioactive compounds has been observed to be effective in inhibition of $R$. solanacearum by Chellemi et al. 1997 and Narasimha et al. 2015. Bioactive compounds are different organic compounds which can exhibit diverse and versatile antimicrobial activities and can enhance different biological activities in any living organism (Shukla 2015, Gupta and Rana 2016). There are several bioactive compounds which show different level of antibacterial competence against both Gram positive and Gram negative type of bacteria (Karim and Hossain 2018). Honey and propolis were found to be very effective against both Gram negative and positive type bacterial management (Miorin et al. 2003). A wide range of pharmacological attributes of curcumin from turmeric were documented for antimicrobial and protective properties (Nagabhushan and Bhide 1992). Cow dung was reported to contain antibiotic agents (Waziri and Suleiman 2013). Magnesium salt in some experiments typically showed positive effects as a stress enhancer of Gram negative Escherichia coli (Oyarzua et al. 2014). Two traditional aromatic rice genotypes, viz. Kalijira and Chinigura, were effectively inhibited a Gram negative Agrobacterium species (Mannan et al. 2014). Iodine (mixed with a transporter known as iodofore) successfully inhibited aerobic Gram positive and Gram negative bacteria (Estrela et al. 2006). Sodium bicarbonate was reported to show antibacterial properties against different types of bacterial and fungal pathogens (Kelly and Kristin 2005). It was also observed that functional diversity of bacteria was influenced by application of organic compounds in farm land due to the positive correlation of $\mathrm{pH}$, organic matter and water content (Chou et al. 2017). Little works have been performed to investigate the antibacterial effectiveness of such bioactive compounds against $R$. solanacearum. Therefore, the study emphasizes the effectiveness of such bioactive compounds in managing the disease severity and virulence of wilt bacteria ( $R$. solanacearum) in potato.

\section{MATERIAL AND METHODS}

Ten bioactive treatments (Table 1) and, a negative control (distilled water), a standard control (stable bleaching powder frequently used by farmers) and a chemical control (Krosin AG - a bactericide containing $9 \%$ streptomycin sulphate and $1 \%$ tetracyline hydrochloride) were evaluated to find out the effectiveness in managing bacterial wilt ( $R$. solanacearum) of potato by different methods (in vitro, in vivo and pot house condition). Suspension of the selected bioactive compounds were prepared as follows: (a) $\mathrm{T}_{1} /$ Control (sterile water)- sterile distilled water was applied as per requirement; (b) $\mathrm{T}_{2} /$ Propolis (@6mg/ml)-propolis was weighed and soaked in 30\% ethanol for $24 \mathrm{hrs}$. Then ethanol soaked ball of propolis was blended and mixed with water to prepare $6 \mathrm{~g} / \mathrm{liter}(6 \mathrm{mg} / \mathrm{ml})$ of propolis; (c) $\mathrm{T}_{3} /$ Honey (@20\%)-200g honey was freshly mixed per liter of distilled water and kept in room temperature to be applied; (d) $\mathrm{T}_{4} /$ Turmeric \& oil (@25\%)- commercial turmeric powder and mustard oil was mixed @ 1:1 and $250 \mathrm{~g}$ of it was mixed freshly with per liter of distilled water. The thick suspension was applied by using dropper or teaspoon as per required; (e) $\mathrm{T}_{5} /$ Turmeric powder (@25\%)- 250g of commercial turmeric powder was mixed in a liter of distilled water which was used freshly; (f) $\mathrm{T}_{6} /$ Magnesium chloride (@3\%)- magnesium chloride salt was collected from market and prepared as 30g per liter of distilled water and stored in room temperature; (g) $\mathrm{T}_{7} /$ Boiled aromatic rice fluid (@10\% ie. 100ml/liter)- fresh kalojira rice was bought from market. After cleaning $100 \mathrm{~g}$ of the rice it was boiled into a thick soup and was mixed @ 100ml per liter of distilled water (@10\%) after straining the fluid and stored in $6{ }^{\circ} \mathrm{C}$ temperature; (h) $\mathrm{T}_{8} /$ Boiled aromatic rice fluid + Iodine (@10\% ie. 100m1/liter + 2 drops of iodine per $100 \mathrm{ml}$ )- it was prepared in the same manner as $\mathrm{T}_{7}$ and just added 20 drops of iodine solution per 1000ml which was bought from market; (i) $\mathrm{T}_{9} /$ Cow dung powder solution (@25\%)- well decomposed and sun dried cow dung was weighed for $250 \mathrm{~g}$ and brought to powder form by using 
mortar and pestle. It was then mixed with $1000 \mathrm{ml}$ distilled water by vigorous shaking and stored in room temperature to be applied as treatment; (j) $\mathrm{T}_{10} /$ Krosin AG (Bactericide @ 0.5 g per liter water)- it was bought from market and applied at the suggested rate by the company; (k) $\mathrm{T}_{11} /$ Honey + Iodine (@2 drops of iodine per $100 \mathrm{ml}$ of $20 \%$ solution of honey)- honey solution was freshly made as previous and just 20 drops of iodine was added in $1000 \mathrm{ml}$ of that $20 \%$ solution and well shaken and kept in room temperature; (1) $\mathrm{T}_{12}$ / Sodium bicarbonate (@10\%)- it was brought from market and weighed 100g and added per liter of distilled water and stored in room temperature; and (m) $\mathrm{T}_{13} /$ Stable bleaching powder (@23mg/kg- as application rate is $30 \mathrm{~kg} / \mathrm{ha}$, soil area $=10000 \mathrm{~m}^{2}$, approx. soil volume $=1000 \mathrm{~m}^{3} / \mathrm{ha}$ as soil depth is $0.1 \mathrm{~m}$, soil bulk density $=1.3 \mathrm{t} / \mathrm{m}^{3}$ and weight of soil=(1000 X 1.3 $)=1300 \mathrm{t} / \mathrm{ha}$; ie. $30 \mathrm{~kg} /$ $1300,000 \mathrm{~kg}$ )- it was also bought from market, calculated and weighed for $23 \mathrm{mg} / \mathrm{kg}$ to make freshly $23 \mathrm{mg}$ in 1litre of distilled water to make the suspension to test in vitro. To be applied in soil, $23 \mathrm{mg}$ of it was mixed with $1 \mathrm{~kg}$ of powdery sterilized soil. Then it was applied.

Table. 1. Treatments, dosage and bioactive ingredients of the selected compounds for evaluation of effectiveness against $R$. solanacearum.

\begin{tabular}{|c|c|c|}
\hline Treatment and Dosage & Bioactive ingredient & Reference \\
\hline $\begin{array}{l}\mathrm{T}_{1}=\text { Control (sterile water as negative } \\
\text { control) }\end{array}$ & - & \\
\hline $\mathrm{T}_{2}=$ Propolis $(@ 6 \mathrm{mg} / \mathrm{ml})$ & Phenolics \& flavonoids & Rahman et al. (2010). \\
\hline $\mathrm{T}_{3}=$ Honey $(@ 20 \%)$ & $\begin{array}{r}\text { Hydrogen peroxide }(\mathrm{H} 2 \mathrm{O} 2), \mathrm{I} \\
(\mathrm{MGO}) \& \text { different en }\end{array}$ & $\begin{array}{l}\text { Majtan et al. (2014); Balan et al. } \\
\text { (2016). }\end{array}$ \\
\hline $\mathrm{T}_{4}=$ turmeric powder \& oil $(@ 25 \%)$ & Curcumin (diferuloyl methane) & Balan et al. (2016). \\
\hline $\mathrm{T}_{5}=$ Turmeric powder $(@ 25 \%)$ & Curcuminoids which are fat soluble & Narasimha et al. (2015). \\
\hline $\mathrm{T}_{6}=$ Magnesium chloride $(@ 3 \%)$ & $\begin{array}{l}\mathrm{Mg}+2 \text { as enzymatic co-factors, as } \\
\text { signaling molecules }\end{array}$ & Oyarzúa et al. (2014). \\
\hline $\begin{array}{l}\mathrm{T}_{7}=\text { Boiled aromatic rice fluid } \\
(@ 10 \% \text { ie. } 100 \mathrm{ml} / \mathrm{liter})\end{array}$ & $\begin{array}{l}\text { Rice-fluid contains rice phytochemicals } \\
\text { viz. oryzanols, anthocyanins, amino } \\
\text { acids, essential oils, phenolics, etc. }\end{array}$ & $\begin{array}{l}\text { Ishizone et al. (2007); Kawakami et al. } \\
\text { (2006); Chakuton et al. (2012); Deng et } \\
\text { al. (2013); Mannan et al. (2014). }\end{array}$ \\
\hline $\begin{array}{l}\mathrm{T}_{8}=\text { boiled aromatic rice fluid }+ \\
\text { iodine }(@ 10 \% \text { ie. } 100 \mathrm{ml} / \mathrm{liter}+2 \\
\text { drops iodine per } 100 \mathrm{ml})\end{array}$ & $\begin{array}{l}\text { Phytochemicals oryzanols, anthocyanins, } \\
\text { amino acids, essential oils, phenolics etc. } \\
\text { \& disinfectant }\end{array}$ & $\begin{array}{l}\text { Mannan et al. (2014); Estrela et al. } \\
\text { (2006). }\end{array}$ \\
\hline $\begin{array}{l}\mathrm{T}_{9}=\text { Sun dried cow dung powder } \\
(@ 25 \%)\end{array}$ & $\begin{array}{c}\text { Large number of microorganisms } \\
\text { produces metabolites, like } \mathrm{k}, \mathrm{Na}, \mathrm{Mg} \text { etc. } \\
\text { in higher levels acting as cofactors for } \\
\text { various enzymes. }\end{array}$ & $\begin{array}{l}\text { Shrivastava et al. (2014); Waziri and } \\
\text { Suleiman (2013). }\end{array}$ \\
\hline $\begin{array}{l}\mathrm{T}_{10}=\text { Krosin AG bactericide (@0.5 g } \\
\text { per liter water as chemical control) }\end{array}$ & $\begin{array}{l}\text { Streptomycin sulphate } 9.0 \%(\mathrm{w} / \mathrm{w}) \& \\
\text { Tetracyline hydrochloride } 1.0 \%(\mathrm{w} / \mathrm{w}) \text {, } \\
\text { broad spectrum antibiotic }\end{array}$ & $\begin{array}{l}\text { Company packet marketed by Krishi } \\
\text { Rasayan Export Pvt. Ltd., India. }\end{array}$ \\
\hline $\begin{array}{l}\mathrm{T}_{11}=\text { Honey }+ \text { Iodine } \\
\text { (@2 drops of iodine per } 100 \mathrm{ml} \text { of } \\
20 \% \text { solution })\end{array}$ & $\begin{array}{c}\text { Hydrogen peroxide }\left(\mathrm{H}_{2} \mathrm{O}_{2}\right), \\
\text { Methylglyoxal (MGO)\& different } \\
\text { enzymes; disinfectants }\end{array}$ & $\begin{array}{l}\text { Secor and Gudmestad (1993); Estrela et } \\
\text { al. (2006); Majtan et al. (2014); Balan } \\
\text { et al. (2016). }\end{array}$ \\
\hline $\mathrm{T}_{12}=$ Sodium bicarbonate $(@ 10 \%)$ & $\begin{array}{c}\text { Nahcolite, acid neutralizing and changes } \\
\text { osmotic pressure which causes microbes } \\
\text { to lose water and dehydrate }\end{array}$ & Kelly and Kristin (2005). \\
\hline $\begin{array}{l}\mathrm{T}_{13}=\text { Stable bleaching powder }(@ \\
23 \mathrm{mg} / \mathrm{kg} \text { as standard control). }\end{array}$ & $\begin{array}{l}\text { Active chlorine } 20-70 \% \text { compromises the } \\
\text { lipid membrane of bacteria }\end{array}$ & Sharma and Kumar (2000). \\
\hline
\end{tabular}

Since differences between virulent and avirulent forms of Ralstonia solanacearum can be recognized on TZC (Triphenyl teterazolium chloride) semi selective media (Mikhail et al. 2017), prepared suspension of bioactive compounds were then screened on TZC solid media in producing inhibition zones $(\mathrm{mm})$ and in colony counts $(\mathrm{cfu} / \mathrm{ml})$ of virulent $\&$ avirulent colonies of $R$. solanacearum in disc 
diffusion method following Bonev et al. (2008) and Liu et al. (2012), as it shows phenotypic conversion (PC) phenomena (Alvarez et al. 2010). The individual colony of virulent and avirulent type was described by Liu et al. (2004) and Zheng et al. (2014) (Fig. 1) and TZC plated avirulent colony types were documented by Kumar et al. (2017). Those were taken into consideration during the study in counting virulent and avirulent forms of colonies (Fig. 1) by using colony counter. Petri plate inoculation was done through disc diffusion method @ four to five colonies of the organism per $4 \mathrm{ml}$ of sterile water which was incubated for 3 to $4 \mathrm{~h}$ (Bauer et al. 1966). Then, that suspension of $R$. solanacearum was suspended on the petri plates by using sterile cotton swabs. Later, the discs (about 6 $\mathrm{mm}$ in diameter) of whatman no. 1 filter paper impregnated with selected bioactive compounds @ 10 microlitres from the prepared doses were placed on to the inoculated TZC plates and incubated at $28^{\circ} \mathrm{C}$ for 36-48 hrs which were replicated for three times. Later, measurements were taken on inhibition zones following Balouiri et al., 2016. For ease of work, media plates and broth following proper autoclaving were kept ready in the freeze at $6{ }^{0} \mathrm{C}$ to use in checking for colony counting.

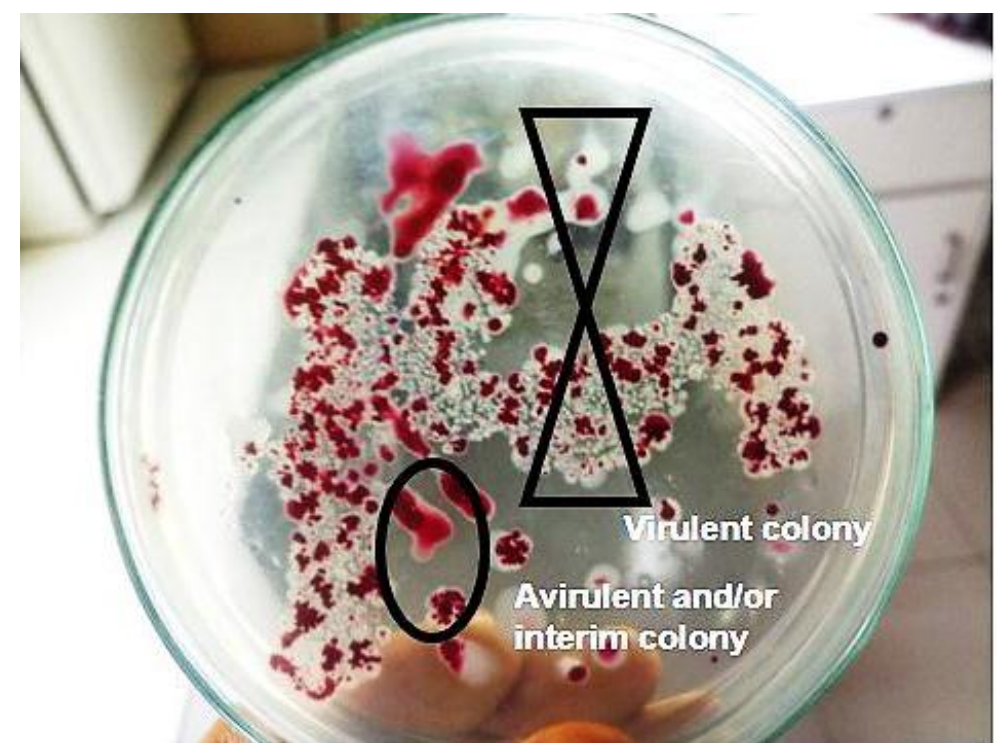

Fig. 1. Virulent and avirulent colonies of $R$. solanacearum TZC solid medium in the study.

To evaluate those compounds as treatment, Ayana et al. (2011), Singh et al. (2014) and Zhang et al. (2015) were followed for inoculation methods and disease scoring of virulence expression. For in vivo evaluation of those bioactive compounds, three weeks old potato seedlings were planted in the seedling tray which was filled with treated soils. Sterilized soils were treated with the suspension of bioactive compounds and inoculated with soil soak method (Zhang et al. 2015) before planting of potato seedlings (at $3^{\text {rd }}$ week) and freshly prepared $R$. solanacearum culture $\left(@ 10^{8} \mathrm{cfu} / \mathrm{ml}\right.$ ) in sterile water medium containing $10 \%$ dextrose (Alvarez et al. 2010) was used to inoculate the soil. The inoculated seedlings were later observed up to two weeks post inoculation $\left(4^{\text {th }}\right.$ and $\left.5^{\text {th }}\right)$ to record the virulence expression. To study the effect on mature plants in unsterilized soil (just solarized), potato seeds were treated with suspension of bioactive compounds. Root trimming inoculation of $5^{\text {th }}$ week old potato plants were done following Kumar et al. (2017) to understand the performance of treatments in natural field soil against the wilt bacteria ( $R$. solanacearum). The seedlings were observed up to 2 WPI (weeks post inoculation ie. $6^{\text {th }}$ and $7^{\text {th }}$ week of plants) to record the disease response of those treatments in virulence expression in terms of disease severity score. The study was done following Tanaka and Noda (1973) and previous other literatures. Depending on those responses (in vitro and in vivo) propolis, turmeric powder and cow 
dung were selected as seed and soil treatment for trial study. Potato seeds and soils (unsterilized but solarized) of treatment cages were treated with propolis $\left(\mathrm{T}_{2}\right)$, cow dung $\left(\mathrm{T}_{4}\right)$ and turmeric powder $\left(\mathrm{T}_{5}\right)$ along with control (sterile water as $\mathrm{T}_{1}$ ) and standard control (stable bleaching powder as $\mathrm{T}_{3}$ ) at the specific doses (as described earlier) to compare those compounds in virulence reduction in field soil condition against $R$. solanacearum. Lemessa and Zeller (2007), Ayana et al. (2011), Singh et al. (2014) and Zhang et al. (2015). For treating the soil, 1 part each treatment suspension was mixed with 3 part of sterile soil powder to get a granular context which was then applied per pit of each treatment. Treated soils were soil-soak inoculated at $2^{\text {nd }}$ week after treatment application. For seed treating, selected treatment suspensions were mixed with sterile soil suspension to make slurry like concentration. Seeds were dipped into slurry of treatment before sowing in the treated and inoculated soil cages. Later, treated seeds were pinch inoculated following Lemessa and Zeller (2007). After that, plants were observed up to $7^{\text {th }}$ WPI (week post inoculation) for disease virulence measurement of the treatments. To understand the effect on pathogen colonization in treated soil, virulent and avirulent colonies of $R$. solanacearum were counted $(\mathrm{cfu} / \mathrm{ml})$ from those five treated soils in dilution plate method (at two level of soil dilution ie. $10^{-5}$ and $10^{-7}$ level). Virulent and avirulent colonies were counted on TZC solid media following Zheng et al. (2014) and Kumar et al. (2017) methods at $7^{\text {th }}$ WPI.

Disease virulence was measured by scoring in a six point rating scale (0-5) following Swanson et al. (2005). Ayana et al. (2011) and Zheng et al. (2014) modified from Winstead and Kelman (1952) which suggested- $0=$ no wilt symptoms, 1 = one/few/one third of whole leaves showing wilted symptoms, $2=$ several/more/half of whole leaves showing wilted symptoms, $3=$ most leaves/two third of whole leaves showing wilted symptoms, $4=$ whole plant showing wilted symptoms and, $5=$ death (collapse) of the whole plant. Since all of the plants showed disease symptoms, the incidence was $100 \%$ in all the cases due to artificial inoculation. So, percent severity index (PSI) was calculated to differentiate the treatment effects as described by Cooke (2006). PSI $=\Sigma($ scores $\times 100) /($ number of plants rated $\times$ maximum scale of the scores) for each scoring date. All those evaluations were performed at least with three to four replications in calculating mean, standard deviation, severity score and PSI. Data were compiled, tabulated and subjected to statistical significance test by using MSTAT-C and $t$-test in data analysis tool Pak software and percent reduction over lowest in excel of windows10 following Gomez and Gomez (1984) and Zhang et al. (2015).

\section{RESULTS AND DISCUSSION}

For screening (in vitro) of bioactive compounds in producing inhibition zone ( $\mathrm{mm}$ ) and colony counts (virulent $\&$ avirulent in $\mathrm{cfu} / \mathrm{ml}$ ) of $R$. solanacearum on TZC solid media, it was observed that significantly largest zone was expressed by $T_{9}$ which was followed by $T_{5}, T_{7}$ and $T_{11}$ whereas the smallest zone was found in $\mathrm{T}_{1}$ (control) (Table 2, Fig. 2, $* * \mathrm{p}<0.01$ ). In case of performances of the compounds in producing virulent and avirulent colonies $(\mathrm{cfu} / \mathrm{ml}$ in per square $\mathrm{cm})$ it was observed that the lowest count of virulent colony was produced by $\mathrm{T}_{2}$ which was followed by $\mathrm{T}_{5}$ and $\mathrm{T}_{9}$ whereas the significant highest virulent colony count was observed in $\mathrm{T}_{1}$ (control) (Table 2; Fig. 2; **p<0.01).

In case of evaluation (in vivo) of those compounds in potato seedlings in sterilized soil it was observed that the lowest significant DSS (disease severity score) was produced by $\mathrm{T}_{7}$ which was followed by $\mathrm{T}_{13}, \mathrm{~T}_{9}$ and $\mathrm{T}_{3}$ whereas highest significant score of that was produced by $\mathrm{T}_{1}(\mathrm{control})$ in $2^{\text {nd }}$ WPI of seedlings against $R$. solanacearum (Fig. 3, **p<0.01).

In the evaluation of those compounds in mature potato plants in unsterilized field soil (just solarized) it was found that the lowest significant DSS (disease severity score) occurred at $\mathrm{T}_{9}$ which was followed by $\mathrm{T}_{2}, \mathrm{~T}_{5}, \mathrm{~T}_{13}$ and $\mathrm{T}_{6}$ whereas significant highest DSS was observed by $\mathrm{T}_{1}$ (control) which was followed by the rest treatments in $2^{\text {nd }}$ WPI in potato plants against $R$. solanacearum (Fig. $4, * * \mathrm{p}<0.01$ ). 
Table 2. Inhibition zone and colony counts of $R$. solanacearum in selected bioactive compounds.

\begin{tabular}{lccc}
\hline Treatment & $\begin{array}{c}\text { Mean Inhibition } \\
\text { zone }(\mathbf{m m})\end{array}$ & $\begin{array}{c}\text { Mean colony count of } \boldsymbol{R} . \\
\text { solanacearum }(\mathbf{c f u} \text { /ml per square cm) }\end{array}$ \\
\cline { 3 - 4 } & & $\begin{array}{c}\text { Virulent } \\
\text { Avirulent }\end{array}$ \\
\hline $\mathrm{T}_{1}=$ Sterile water (negative control) & $8.48 \pm 0.53$ & $53.10 \pm 17.43$ & $4.62 \pm 5.49$ \\
$\mathrm{~T}_{2}=$ Propolis & $14.46 \pm 0.58$ & $8.23 \pm 8.17$ & $13.43 \pm 4.03$ \\
$\mathrm{~T}_{3}=$ Honey & $16.24 \pm 0.62$ & $37.69 \pm 14.70$ & $9.42 \pm 17.30$ \\
$\mathrm{~T}_{4}=$ Turmeric + oil & $17.39 \pm 2.20$ & $33.59 \pm 7.42$ & $42.75 \pm 5.61$ \\
$\mathrm{~T}_{5}=$ Turmeric powder & $20.19 \pm 1.64$ & $11.72 \pm 4.34$ & $16.86 \pm 9.58$ \\
$\mathrm{~T}_{6}=$ Magnesium chloride & $15.07 \pm 0.69$ & $29.68 \pm 11.17$ & $9.89 \pm 13.16$ \\
$\mathrm{~T}_{7}=$ Boiled rice fluid & $17.89 \pm 0.56$ & $27.66 \pm 13.46$ & $5.66 \pm 12.85$ \\
$\mathrm{~T}_{8}=$ Boiled rice fluid + Iodine & $14.84 \pm 0.77$ & $30.21 \pm 6.67$ & $15.56 \pm 7.66$ \\
$\mathrm{~T}_{9}=$ Cow dung powder & $20.69 \pm 1.10$ & $12.21 \pm 5.34$ & $64.12 \pm 10.30$ \\
$\mathrm{~T}_{10}=$ KrosinAG (chemical control) & $17.18 \pm 0.86$ & $47.83 \pm 5.67$ & $22.51 \pm 7.73$ \\
$\mathrm{~T}_{11}=$ Honey + Iodine & $17.73 \pm 1.25$ & $36.55 \pm 6.73$ & $10.31 \pm 7.97$ \\
$\mathrm{~T}_{12}=$ Sodium bicarbonate & $13.34 \pm 0.24$ & $39.29 \pm 8.34$ & $4.86 \pm 11.50$ \\
$\mathrm{~T}_{13}=$ Stable bleaching (standard control) & $14.21 \pm 1.21$ & $21.85 \pm 5.74$ & $25.65 \pm 7.04$ \\
\hline & $* * \mathrm{P}$ value $<0.01$ & $* * \mathrm{P}$ value $<0.01$ & $* * \mathrm{P}$ value<0 0.01 \\
\hline
\end{tabular}

In the evaluation of propolis, turmeric powder and cow dung as seed and soil treatment against $R$. solanacearum it was observed that at $7^{\text {th }}$ WPI the lowest significant PSI was occurred at $\mathrm{T}_{4}(60.00 \%$ in cow dung@ $@ 25 \%)$ which was followed by $\mathrm{T}_{2}\left(62.22 \%\right.$ in propolis @ 6mg/ml) and $\mathrm{T}_{5}(66.67 \%$ in turmeric powder @ 25\%) whereas significant highest PSI was observed in $\mathrm{T}_{3}(88.89 \%$ in standard control/ stable bleaching powder @ 23mg/kg) and $\mathrm{T}_{1}(84.44 \%$ in negative control) in natural field soil (Fig. 5, ** $<0.01)$. So, highest significant reduction of PSI over lowest $\left(\mathrm{T}_{3}\right.$ as stable bleaching powder @ 23mg/kg) was occurred at $\mathrm{T}_{4}\left(28.89 \%\right.$ in cow dung @ 25\%) which was followed by $\mathrm{T}_{2}(26.67 \%$ in propolis@6mg/ml).T5 (22.22\% in turmeric powder@ 25\%) was in between $\mathrm{T}_{4}$ and $\mathrm{T}_{2}$ whereas the lowest reduction was occurred in $\mathrm{T}_{1}\left(84.44 \%\right.$ in control) at the $7^{\text {th }} \mathrm{WAI}$ (week post inoculation) (Fig. 6, $* \mathrm{p}<0.05)$.
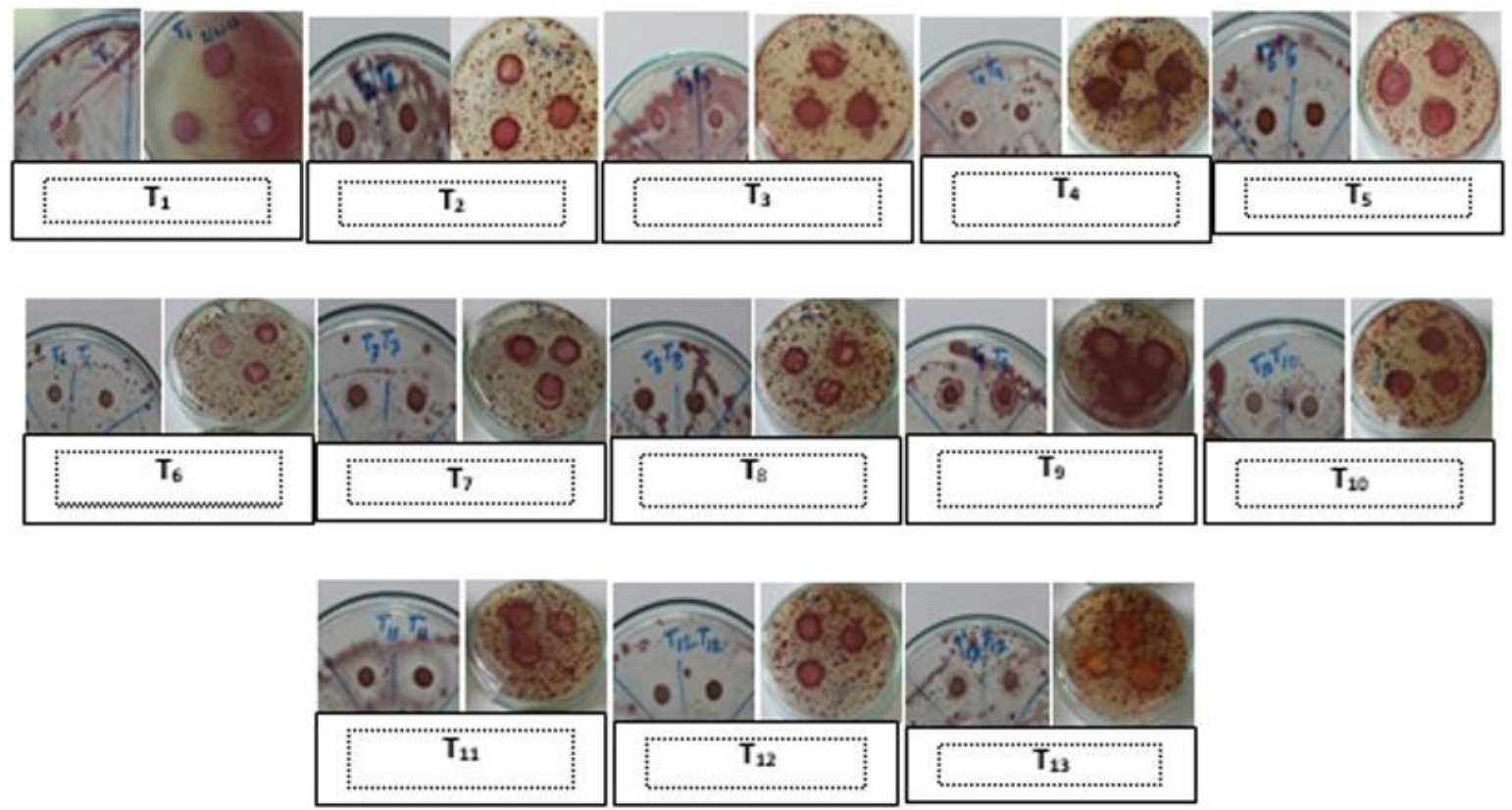

Fig. 2. Bioactive compounds showing inhibition zone $(\mathrm{mm})$ and virulent and avirulent colonies $(\mathrm{cfu} / \mathrm{ml})$ in the treatment plates of $\mathrm{T}_{1}, \mathrm{~T}_{2}, \mathrm{~T}_{3}, \mathrm{~T}_{4}, \mathrm{~T}_{6}, \mathrm{~T}_{7}, \mathrm{~T}_{8}, \mathrm{~T}_{9}, \mathrm{~T}_{10}, \mathrm{~T}_{11}, \mathrm{~T}_{12}$ and $\mathrm{T}_{13}$ against $R$. solanacearum. 
For virulent and avirulent colony counts $\left(\mathrm{cfu} / \mathrm{ml}\right.$ per $\left.\mathrm{cm}^{2}\right)$ in soil of different treatments, it was observed that significantly lowest virulent colony was produced in $\mathrm{T}_{4}$ (26.48 cfu in cow dung @ 25\%) which was followed by $\mathrm{T}_{2}\left(29.44 \mathrm{cfu}\right.$ in propolis @ 6mg/ml, comparatively dry colonies) and $\mathrm{T}_{5}(33.54$ cfu in turmeric powder @ 25\%) whereas the highest of that was found in case of $\mathrm{T}_{3}(65.71 \mathrm{cfu}$ in stable bleaching powder @ 23mg/kg) which was followed by $\mathrm{T}_{1}(55.10 \mathrm{cfu}$ in control) (Fig. 8, **p<0.01). On the other hand, significant highest avirulent colony count was found in case of $\mathrm{T}_{5}(52.46 \mathrm{cfu}$ in turmeric powder@ 25\%) which was followed by $\mathrm{T}_{4}$ (49.18 cfu in cow dung @ 25\%) and $\mathrm{T}_{2}(31.89 \mathrm{cfu}$ in propolis@6mg/ml)whereas the lowest of that was occurred in case of $\mathrm{T}_{3}$ (8.96 cfu in stable bleaching powder @ $23 \mathrm{mg} / \mathrm{kg}$ ) which was followed by $\mathrm{T}_{1}(39.90 \mathrm{cfu}$ in control) (Fig. 7, **p<0.01). Thus, differences of virulent and avirulent colony counts (Fig. 8) of soil collected from different treatments were reflected in TZC plated solid media at $5^{\text {th }}$ week post inoculation.

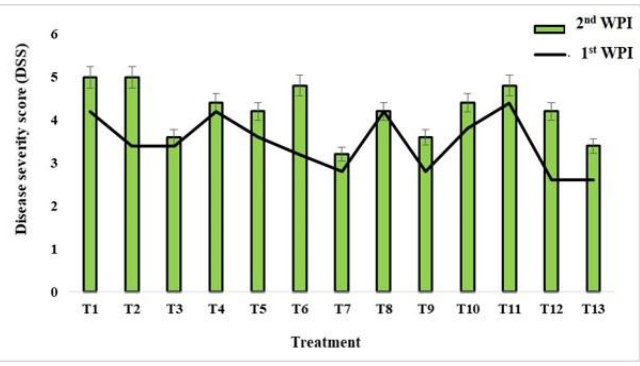

Fig. 3. Disease severity score (DSS) of the bioactive compounds in potato seedlings in sterilized soil against $R$. solanacearum at $1^{\text {st }}$ and $2^{\text {nd }}$ WPI (weeks post inoculation) $\left(^{* *} p<0.01\right)$.

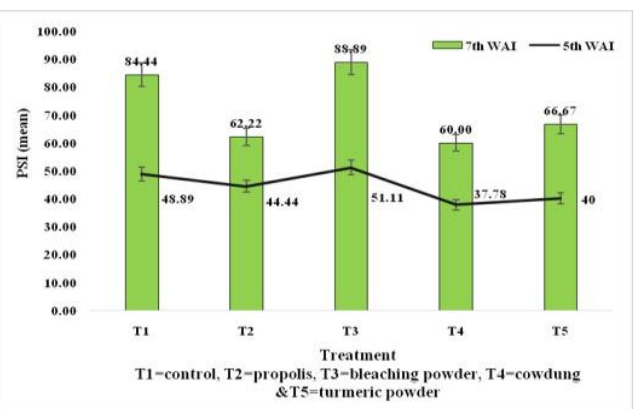

Fig. 5. PSI (Percent severity index) of propolis, cow dung and turmeric powder as both seed and soil treatment compared to controls (negative and standard) against wilt disease $(R$. solanacearum $)$ in $5^{\text {th }}$ and $7^{\text {th }}$ WPI $(* * \mathrm{p}<0.01)$.

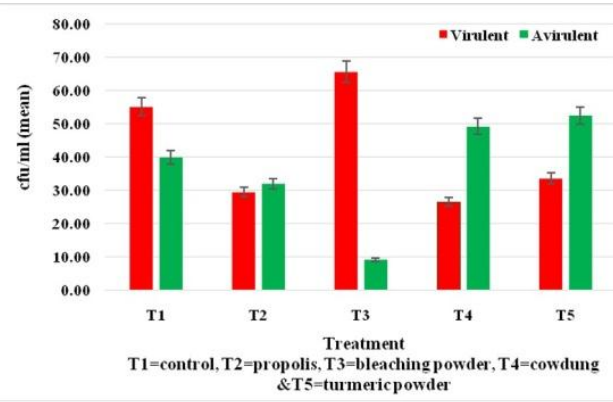

Fig. 7. Virulence expression (virulent \& avirulent colony count/square $\mathrm{cm}$ ) of $R$. solanacearum in soil dilution plates (@10 10 level) from different treatments on $7^{\text {th }}$ WPI $(* * \mathrm{p}<0.01)$.

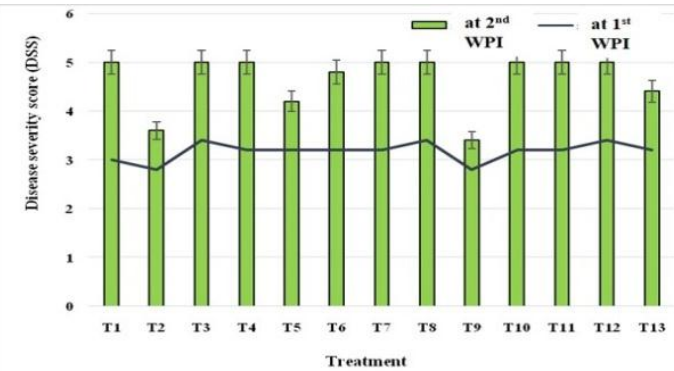

Fig. 4. Disease severity score (DSS) of the bioactive compounds in $1^{\text {st }}$ and $2^{\text {nd }}$ WPI (week post inoculation) of potato plants in unsterilized soil (just solarized) against wilt pathogen (R. solanacearum) $\left.{ }^{* *} \mathrm{p}<0.01\right)$.

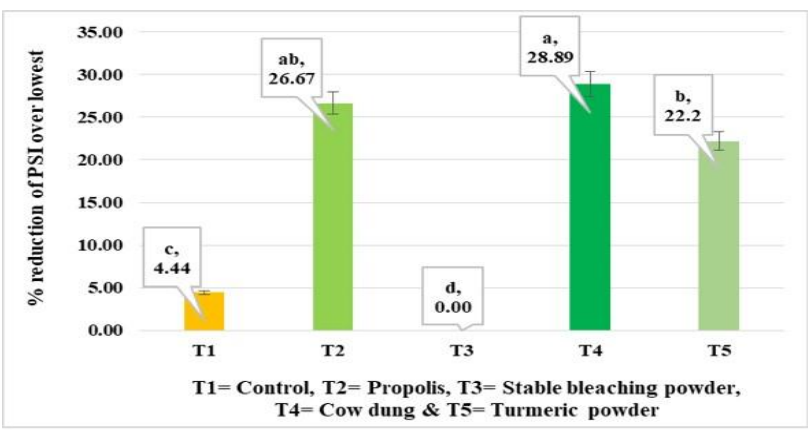

Fig. 6. Percent reduction of PSI of wilt disease (R. solanacearum) at $7^{\text {th }}$ WPI in propolis, turmeric powder and cow dung treatment $(* \mathrm{p}<0.05)$.

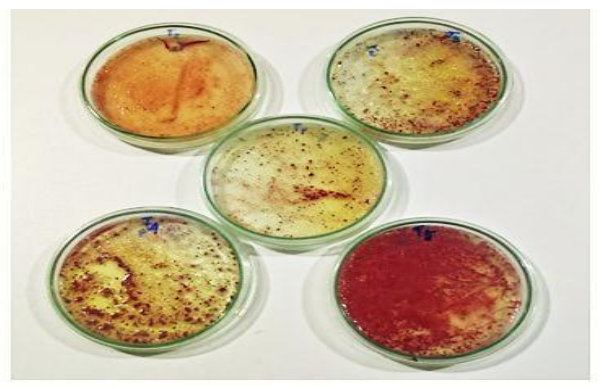

Fig. 8. Virulent and avirulent colony expression of $R$. solanacearum in soil dilution plates (a) $10^{-5}$ level) of different treatments on $7^{\text {th }}$ WPI. 
Several traditional control strategies viz. quarantine, breeding for resistance, biological control and chemical control has been applied worldwide, but no single management practice controlled the wilt disease ( $R$. solanacearum) successfully in potato crop (Karim et al., 2018). Nevertheless, some bioactive compounds have been effective in inhibition of many dangerous strains of bacteria (Leksomboon et al. 2000) and $R$. solanacearum (Chellemi et al. 1997, Narasimha et al. 2015). Thus, ten bioactive compounds (viz. propolis, honey, tumeric powder, $\mathrm{MgCl}_{2}$ salt, aromatic rice fluid, iodine, cow dung and sodium bicarbonate) were selected to test against $R$. solanacearum of potato following the review study of Karim and Hossain (2018). In disc diffusion method (in vitro) all of the treatments except control produced inhibition zones. But, in unsterilized soil only propolis, turmeric powder and cow dung showed very positive response in severity reduction of wilt disease in artificial inoculation. But, commercial bactericide Krosin AG (a compound containing 9\% streptomycin sulphate and 1\% tetracyline hydrochloride) found to perform lower during the study which was found parallel to the study of Farag et al. (1982 and 1986) in CABI (2017). Based on the performances of in vitro and in vivo evaluation suspension of propolis, turmeric powder and cow dung were trialed as both soil and seed treatment in artificially inoculated potato plants with $R$. solanacearum as functional diversity of bacteria can be influenced by application of organic compounds (Chou et al. 2017). All of the three appeared very much effective in reducing the disease virulence (severity index and colony counts) of pathogen compared to control and stable bleaching powder. The reasons of their antibacterial efficacy were methodically studied by several researchers. Chemical composition and antibacterial activity of propolis were studied by Bosio et al. (2000) and Miorin et al. (2003). They found that bee propolis is rich in flavonoids and phenolics which is why it exhibits antibacterial properties. Several similar studies were done by Zumla and Lulat (1989), Martos et al. (1997), Nieva Moreno et al. (1999) and Marcucci et al. (2001) and, those studies verified that phenolics of propolis including cinnamic acid derivatives and flavonoids were exhibiting antibacterial properties. Rahman et al. (2010) studied the concentration of propolis as antibacterial agent and observed that higher concentration of propolis can produce greater inhibition zones against both Gram negative type Escherichia coli and Gram positive type Staphylococcus aureus. However, Miorin et al. (2003) suggested that the extent of effectiveness of propolis and their chemical composition varies depending on bee species and geographic region. Turmeric (Curcuma longa L.) was researched in medicinal context by Eigner and Scholz (1999) and Gupta et al. (2012). They found it as an extensively used medicinal plant for numerous pathological research due to the presence of curcumin (diferuloyl methane) with a wide range of attributes, such as antioxidative, antimicrobial and wound-healing properties which was parallel to the findings of Nagabhushan and Bhide (1992), Aggarwal and Harikumar (2009), Frenkel et al. (2013), Moghadamtousi et al. (2014) and many others. In a study, Narasimha et al. (2015) found 10\% (w/v) turmeric powder to produce an inhibition zone (in vitro) from 15 to $25 \mathrm{~mm}$ against several virulent strains of $R$. solanacearum that is in support to present study. However, it was observed that application @ $25 \%(\mathrm{w} / \mathrm{v})$ was doing better in unsterilized soil in pre-evaluation of the study. In different researches, Sethuraman and Ray (2003) and many others studied the composition of cow dung and their antibacterial properties. Sethuraman and Ray (2003) found it to contain approx. $80 \%$ water and a matrix of undigested plant material rich in nutrients, micro-organisms, and their byproducts which was corresponding to the findings of Nene (2003) and Randhawa and Kullar (2011). But, Khanuja (2002), Waziri and Suleiman (2013) and Shrivastava et al. (2014) found it to contain antibiotic agents showing higher effectiveness against both Gram negative and Gram positive type bacteria. The presence of $\mathrm{k}$, Na, $\mathrm{Mg}$ and many other elements at higher levels in cow dung were described by Waziri and Suleiman (2013) in the study. Those elements act as enzymatic cofactors in different biochemical processes in relation to antibacterial activity which was also revealed by Gupta et al. (2016). However, in the study 
of seed and soil treatment, stable bleaching powder was observed to perform lower compared to control which might be due to the reaction of bleaching powder with organic matters in the soil. Because application of stable bleaching powder reduces the bacterial population on small scale (Saddler 2005) but it can be inactivated by organic matter by releasing a toxic chlorine gas (Kennedy and Bek. 1998).

\section{REFERENCES}

Aggarwal, B. B. and K. B. Harikumar. 2009. Potential therapeutic effects of curcumin, the anti-inflammatory agent, against neurodegenerative, cardiovascular, pulmonary, metabolic, autoimmune and neoplastic diseases. Int. J. Biochem. Cell. Biol. 41: 40-59.

Alvarez, B., E. G. Biosca and M. M. Lopez. 2010. On the life of Ralstonia solanacearum, a destructive bacterial plant pathogen. In: A. Mendez-Vilas (ed.). Current Research, Technology and Education Topics in Applied Microbiology and Microbial Biotechnology. FORMATEX., pp. 267-279.

Ayana, G., C. Fininsa, S. Ahmed and K. Wydra. 2011. Effects of soil amendment on bacterial wilt caused by Ralstonia solanacerum and tomato yields in Ethiopia. J. Plant Protection Res. 51(1):72-76.

Balan, P., G. Mal, S. Das and H. Singh. 2016. Synergistic and additive antimicrobial activities of curcumin, manuka honey and whey proteins. J. Food Biochem. 40: 647-654.

Balouiri, M., M. Sadiki and S. K. Ibnsouda. 2016. Methods for in vitro evaluating antimicrobial activity: A review. J. Pharma. Anal. 6: 71-79.

Bauer, A. W., W. M. Kirby, J. C. Sherris and M. Turck. 1966. Antibiotic susceptibility testing by a standardized single disc method. Am. J. Clin. Pathol. 45: 493-496.

Bonev, B., J. Hooper and J. Parisot. 2008. Principles of Assessing Bacterial Susceptibility to Antibiotics Using the Agar Diffusion Method. J. Antimicrobial Chemotherapy. 61(6): 1295-1301.

Bosio, K, C. Avanzini, A. D'Avolio, O. Ozino and D. Savoia. 2000. In vitro activity of propolis against Streptococcus pyogenes. Let. App. Microb. 31: 174-177.

CABI. 2017. Invasive Species Compandium: Datasheets, maps, images, abstracts and full text on invasive species of the world. Datasheet - Ralstonia solanacearum (bacterial wilt of potato).

Chakuton, K., D. Puangpronpitag and M. Nakornriab. 2012. Phytochemical content and antioxidant activity of colored and non-colored Thai rice cultivars. Asian J. Plant Sci. 11: 285-293.

Champoiseau, P. G., J. B. Jones and C. Allen. 2009. Ralstonia solanacearum race 3 biovar 2 causes tropical losses and temperate anxieties. Plant Health Progress Online. $10 \mathrm{pp}$.

Chellemi, D. O., H. A. Dankers, S. M. Olson, N. C. Hodge and J. W. Scott. 1997. Evaluating bacterial wiltresistant tomato genotypes using a regional approach. Am. J. Horticultural Sci. 119: 326-329.

Chou, Y., F. Shen, S. Chiang and C. Chang. 2017. Functional diversity and dominant populations of bacteria in banana plantation soils as influenced by long-term organic and conventional farming. Appl. Soil Ecol. 110: 21-33.

Cooke, B. M. 2006. Disease assessment and yield loss. In: B. M. Cooke, D. G. Jone and B. Kaye (eds.). The Epidemiology of Plant Diseases. 2nd ed. Springer, Dorchert. 576 pp.

Deng, G. F., X. R. Xu, Y. Zhang, D. Li, R. Y. Gan and H. B. Li. 2013. Phenolic compounds and bioactivities of pigmented rice. Crit. Rev. Food. Sci. Nutr. 53(3): 296-306.

Eigner, D. and D. Scholz. 1999. Ferula asafoetida and Curcuma longa in traditional medicinal treatment and diet in Nepal. J. Ethnopharmacol. 67: 1-6.

Estrela, C., C. R. A. Estrela, A. C. B. Hollanda, A. D. Decurcio and J. D. Pecora. 2006. Influence of iodoform on antimicrobial potential of calcium hydroxide. J. Appl. Oral Sci. 14(1): 33-7. 
FAOSTAT. 2014. Statistical Database. Food and Agricultural Organization of the United Nations, Rome, Italy.

FAOSTAT. 2017. Statistical Database. Food and Agricultural Organization of the United Nations, Rome, Italy.

Farag, N. S., F. G. Fawzi, S. I. A. El-Said and M. S. Mikhail. 1986. Streptomycin in relation to potato brown rot control. Acta Phytopathologica et Entomologica Hungarica. 21: 115-122.

Farag, N. S., S. M. Lashin, R. S. Abdel-All, H. M. Shatta and A. M. Seif-Elyazal. 1982. Antibiotics and control of potato black leg and brown rot diseases. Agric. Res. Rev. 60(2): 149-166.

Frenkel, M., D. I. Abrams, E. J. Ladas, G. Deng, M. Hardy, J. L. Capodice, M. F. Winegardner, J. K. Gubili, K. S. Yeung, H. Kussmann and K. I. Block. 2013. Integrating dietary supplements in to cancer care. Integr. Cancer. Ther. 12(5): 369-384.

Gadewar, A. V., T. P. Trivedi and G. S. Sekhawat. 1991. Potato in Karnataka. Technical Bulletin 17. CPRI, Shimla, India. $33 \mathrm{pp}$.

Gomez, K. A. and A. A. Gomez. 1984. Statistical procedures for agricultural Research. 2nd ed. John Willy and sons, New York, USA., pp. 97-369.

Gupta, K. K. and D. Rana. 2016. Isolation and Evaluation of Cow Dung Bacteria for Their Antimicrobial Potential. Biotech. Int. 9(2): 47-54.

Gupta, K. K., K. R. Aneja and D. Rana. 2016. Current status of cow dung as a bioresource for sustainable development Bioresour. Bioprocess. 3: 28.

Gupta, S. C., S. Patchva, W. Koh and B. B. Aggarwal. 2012. Discovery of curcumin, a component of golden spice, and its miraculous biological activities. Clin. Exp. Pharmacol. Physiol. 39: 283-299.

Hayward, A. C. 1964. Characteristics of Pseudomonas solanacearum. J. Appl. Bacteriol. 27: 265-277.

Ishizone, S., F. Maruta, K. Suzuki, S. Miyagawa, M. Takeuchi, K. Kanaya, K. Oana, M. Hayama, Y. Kawakami and H. Ota. 2007. In vivo bactericidal activities of Japanese rice-fluid against $H$. pylori in a Mongolian gerbil model. Int. J. Med Sci. 4: 203-208.

Karim, Z. and M. Hossain. 2018. Management of bacterial wilt (Ralstonia solanacearum) of potato: focus on natural bioactive compounds. J. Biodiver. Conserv. Bioresour. Manage. 4(1): 73-92.

Karim, Z., M. S. Hossain and M. M. Begum. 2018. Ralstonia solanacearum: A threat to potato production in Bangladesh. Fundam. Appl. Agric. 3(1): 407-421.

Kawakami, Y., K. Oana, M. Hayama, H. Ota, M. Takeuchi, K. Miyashita, T. Matsuzawa and K. Kanaya. 2006. In vitro bactericidal activities of Japanese rice-fluid against Helicobacter pylori strains. Int. J. Med. Sci. 3: 112-116.

Kelly, J. S. and R. T. Kristin. 2005. Sodium bicarbonate and Hydrogen peroxide: The Effect on the Growth of Streptococcus mutans. J. Dental Hygiene. 79: 4.

Kennedy, J. and J. Bek. 1998. Selection and Use of Disinfectants. Nebraska Cooperative Extension.

Khanuja, S. P. S. 2002. Pharmaceutical composition containing cow urine distillate and an antibiotic. US patent 6410059.

Kumar, S., Kedarnath, N. Hamsaveni, P. H. R. Gowda, I. B. Rohini, K. T. Rangaswamy and R. Achari. 2017. Isolation and characterization of Ralstonia solanacearum causing bacterial wilt of solanaceae crops. Int. J. Curr. Microbiol. App. Sci. 6 (5): 1173-1190.

Leksomboon, C., N. Thaveechai, W. Kositratana and Y. Paisooksantivatana. 2000. Antiphytobacterial activity of medicinal plant extracts. Science. 54: 91-97. 
Lemessa, F. and W. Zeller. 2007. Isolation and characterisation of Ralstonia solanacearum strains from Solanaceae crops in Ethiopia. J. Basic Microbiol. 47: 40-49.

Liu, B., Y. Z. Lin, Y. J. Zhu, C. B. Ge and Y. Cao. 2004. Attenuation characteristics of bacterial wilt disease biocontrol strain Anti-8098A (Bacillus cereus) to Ralstonia solanacearum. J. Agric. Biotech. 12: $322-$ 329.

Liu, Z., X. YU, L. Wang, B. Zhou, X. Ji, Y. Li and Y. Liu. 2012. Analysis of physiological polymorphism of Chinese Tobacco strains of Ralstonia solanacearum. Int. J. Biod. Conserv. 4(6): 267-276.

Majtan, J., J. Bohova, E. Prochazka and J. Klaudiny. 2014. Methylglyoxal May Affect Hydrogen Peroxide Accumulation in Manuka Honey Through the Inhibition of Glucose Oxidase. J. Med. Food. 17(2): 290293.

Mannan, M. A., T. C. Sarker, A. H. Kabir, M. M. Rahman and M. F. Alam. 2014. Antitumor properties of two traditional aromatic rice genotypes (Kalijira and Chinigura). Avicenna J Phytomed. 4(1):31-42.

Marcucci, M. C., F. Ferreres, C. Garcia-Viguera, V. S. Bankova, S. L. De Castro, A. P. Dantas, P. H. M. Valente and N. Paulino 2001. Phenolic compounds from Brazilian propolis with pharmacological activities. J. Ethnopharmacol. 74: 105-112.

Martos, I., M. Conssentini, F. Ferreres and F. Tomas-Barberan. 1997. Flavonoid composition of Tunisian honey and propolis. J. Agric. Food Chem. 54: 2824-2829.

Mikhail, M. S., A. I. Abdel-Alim, N. M. Balabel and A. M. Abbas. 2017. Virulence of Ralstonia solanacearum phylotype ii sequevar i, the causal pathogen of potato brown rot. J. Biol. Chem. Environ. Sci. 21(3): 219-235.

Miorin, P. L., N. C. J. Levy, A. R. Custodio, W. A. Bretz and M. C. Marcucci. 2003. Antibacterial activity of honey and propolis from Apis mellifera and Tetragonisca angustula against Staphylococcus aureus. J. Appl. Microb. 95: 913-920.

Moghadamtousi, S. Z., H. A. Kadir, P. Hassandarvish, H. Tajik, S. Abubakar and K. Zandi. 2014. A review on antibacterial, antiviral, and antifungal activity of curcumin. BioMed Res. Int. 2014(186864): 1-12.

Mukherjee, N. and M. K. Dasgupta. 1989. Udvider Rog (Plant Disease). Poschimbongo Rajyo Pustak Porsad (West Bengal State Book Board) Kolkata, India.

Nagabhushan, M. and S. V. Bhide. 1992. Curcumin as an inhibitor of cancer. Am. Coll. Nutr. 11: 192-198.

Narasimha, M. K., K. Soumya and C. Srinivas. 2015. Antibacterial Activity of Curcuma longa (Turmeric) Plant Extracts against Bacterial Wilt of Tomato Caused by Ralstonia solanacearum. Int. J. Sci. Res. 4(1): 2136-2141.

Nene, Y. L. 2003. Crop diseases management practices in ancient, medieval, and premodern India. Asian Agri-Hist. 7(3): 185-201.

Nieva Moreno, M. I., M. I. Isla, N. G. Cudmani, M. A. Vattuone and A. R. Sampietro. 1999. Screening of bacterial activity of Amaicha Del Valle (Tucuman, Argentina) propolis. J. Ethnopharm. 68: 97-102.

Oyarzua, A. P, K. Sossa, D. Contreras, H. Urrutia and A. Nocker. 2014. Antimicrobial properties of magnesium chloride at low pH in the presence of anionic bases. Magnes. Res. 27(2): 57-68.

Parvez, S. 2017. Potato Exports Fail to Pick UP. The Daily Star(Business). 14 April, 2017.

Rahman, M. M., A. Richardson and M. S. Azirun. 2010. Antibacterial activity of propolis and honey against Staphylococcus aureus and Escherichia coli. Afr. J. Microbiol. Res. 4(16): 1872-1878.

Randhawa, G. K. and J. S. Kullar. 2011. Bioremediation of pharmaceuticals, pesticides, and petrochemicals with gomeya/cow dung. ISRN Pharmacol. 2011(362459): 1-7. 
Saddler, G. S. 2005. Management of bacterial wilt disease. In: C. Allen, P. Prior and A. C. Hayward (eds.). Bacterial Wilt Disease and the Ralstonia solanacearum Species Complex. American Phytopathological Society, St. USA., pp. 121-131.

Sagar, V., A. K. Somani, R. K. Arora, S. Sharma, S. K. Chakrabarti, S. K. Tiwari, R. Chaturvedi and B. P. Singh. 2013. Status of bacterial wilt of potato in the Malwa region of Madhya Pradesh in India. J. Plant Pathology. 95(2): 321-328.

Secor, G. A. and N. C. Gudmestad. 1993. Handling and planting seed tubers. In: R. C. Rowe and D. Curwen (eds.). Potato Health Management. APS press, California, USA., pp. 27-30.

Sethuraman, N. S. K. and P. R. C. Ray. 2003. Sprouting in plants by cow dung slurry. Validation of indigenous technical knowledge in agriculture extension. Indian Council Agric. Res. 2003:197-201.

Sharma, J. P. and S. Kumar. 2000. Management of Ralstonia wilt through soil disinfectant, mulch, lime and cakes in tomato (Lycopersicon esculentum). Indian J. Agric. Sci. 70(1):17-19.

Shrivastava, S., A. Mishra and A. Pal. 2014. Cow dung: A boon for antimicrobial activity. Life Sci. Leaflets. 55: 152.

Shukla, R. 2015. Studies on bioactive compounds from different microorganisms. Int. J. Sci. Engineer. Res. 6(6): 1225-1233.

Singh, D., D. K. Yadav, S. Sinha and G. Choudhary. 2014. Effect of temperature, cultivars, injury of root and inoculums load of Ralstonia solanacearum to cause bacterial wilt of tomato. Archives of Phytopathology and Plant Protection: 47(13): 1574-1583.

Swanson, J. K., J. Yao, J. Tans-Kersten and C. Allen. 2005. Behavior of Ralstonia solanacearum race 3 biovar 2 during latent and active infection of geranium. Phytopathology. 95: 136-143.

Tanaka, Y. and N. Noda. 1973. A study of factors governing the survival of tobacco wilt disease bacteria. Bull. Okayama Tobacco Exp. Stat. 32: 81-93.

USDA (United States Department of Agriculture). 2003. Biological control of Fusarium wilt and other soilborne pathogenic fungi. Project Annual Report.

Waziri, M. and J. S. Suleiman. 2013. Analysis of some element and antimicrobial activity of evaporated extract of cow dung against some pathogens. J. Scientific Res. 5(1): 135-141.

Winstead, N. and A. Kelman. 1952. Inoculation techniques for evaluating resistance to Pseudomonas solanacearum. Phytopathology. 42: 628-634.

Yuliar, Y., A. Nion and K. Toyota. 2015. Recent Trends in Control Methods for Bacterial Wilt Diseases Caused by Ralstonia solanacearum. Microbes Environ. 30(1): 1-11.

Zhang, Y., F. Luo, D. Wu, Y. Hikichi, A. Kiba, Y. Igarashi, W. Ding and K. Ohnishi. 2015. PrhN, a putative marR family transcriptional regulator, is involved in positive regulation of type III secretion system and full virulence of Ralstonia solanacearum. Front. Microbiol. 6: 357.

Zheng, X., Y. Zhu, B. Liu, Y. Zhou, J. Che and N. Lin. 2014. Relationship between Ralstonia solanacearum diversity and severity of bacterial wilt disease in tomato fields in China. J Phytopathol; 162: 607-616.

Zumla, A and A. Lulat. 1989. Honey - a remedy rediscovered. J. R. Soc. Med. 82: 384-385. 